\title{
TRADISI BASUNAT URANG BANJAR : “MEMBACA" MAKNA ANTROPOLOGIS DAN FILOSOFIS
}

\author{
M. Rusydi*
}

\begin{abstract}
Khitan is called circumcision in english. It is the surgical removal of the foreskin from the penis. In Banjarese society, circumcision's celebration is called basunat. Basunat as rite of passage is one of important stages for Banjareses' life. Socially, the tradition maintains the collectiveness and integration of Banjarese society. According to anthropology view, basunat may be understood as a liminal condition. Liminal is a condition of betwixt and between. In this condition, subject of rite experiences a formed stage. Furthermore, according to philosophy view, the tradition reflects the exsistence of buman being and it's relation with other existences.
\end{abstract}

Kata Kunci : Khitan, Basunat, Liminal, Eksistensi.

\section{Pendahuluan}

Basunat dalam tradisi Islam lazimnya disebut dengan khitan. dua istilah ini memiliki kesataraan arti secara harfiah namun memiliki makna yang berbeda pada realitasnya. Khitan adalah operasi kecil terhadap alat kelamin dan merupakan praktek keagamaan dalam kalangan umat Islam. Sedangkan Basunat adalah suatu tradisi yang dilakukan oleh masyarakat Banjar ketika melaksanakan khitan yang diisi dengan berbagai aktivitas ritual.

Dengan demikian, basunat merupakan hasil dialog budaya lokal dan Islam. Hal ini menjadikan basunat sebuah tradisi yang unik di daerah ini. Islam dengan kewajiban khitan bagi pemeluknya, dan masyarakat banjar dengan tradisi lokalnya menghadirkan tradisi basunat dengan simbol-simbol

\footnotetext{
*Penulis adalah alumni UIN Sunan Kalijaga. Pengajar di Fak. Ushuluddin dan Darul
} Hijrah Putri Batung. Contact person : 0511-6138430/085211992648 
keislamanan dan lokalitas seperti pembacaan maulid, piduduk, tanda cacakburung, dan lain sebagainya.

Oleh karena itu, basunat atau khitan yang secara antropologis merupakan masa peralihan dan secara nyata ditandai dengan perubahan status dari anak-anak menjadi dewasa, sangat menarik untuk dipahami makna antropologisnya terutama dengan pendekatan liminal (ambang pintu) Victor Turner yang beranggapan bahwa kondisi liminal adalah masa reflektif formatif yang penting bagi individu untuk memasuki tahap perkembangan hidupnya.

Tindakan reflektif formatif tentu saja meniscayakan pemahaman terhadap makna eksistensial. Makna eksistensial ini meliputi kenyataan yang ada dan dihadapi manusia, dari hubungan vertikal dengan Tuhan hingga hubungan horizontal dengan sesamanya, alam sekitar dan kebudayaan sebagai ciptaan manusia serta kondisi pluralitas (keberagaman) yang merupakan bagian dari hakikat hidup manusia itu sendiri. Untuk menemukan makna ini pada basunat tentu saja memerlukan pembacaan filosofis.

Oleh karena itu, artikel ini bertujuan untuk memberikan deskripsi tradisi basunat yang ada di daerah Banjar dan analisis makna antropologis serta filosofis tradisi tersebut. Tulisan ini berbentuk literatur dengan sumber utama adalah berbagai tulisan tentang tradisi basunat dan sumber penunjang berbagai tulisan yang mendukung tradisi tersebut.

\section{Khitan dan Tradisi Basunat}

\section{Islam dan Khitan}

Khitan disebut juga sirkumsisi (circumcision). Kata sirkumsisi berasal dari bahasa Latin circum berarti memutar dan caedere berarti memotong. Adapun khitan adalah tindakan memotong atau menghilangkan sebagian atau seluruh kulit penutup depan dari alat kelamin laki-laki. ${ }^{1}$ Dalam tradisi Islam khitan dimaknai pula sebagai nama lain alat kelamin lelaki dan perempuan seperti dalam hadis yang mengatakan "Apabila terjadi pertemuan dua khitan, maka telah wajib mandi" (H.R. Muslim, Tirmidzi dll.). ${ }^{2}$

Bagi muslim, khitan juga merupakan salah satu media pensucian diri dan bukti ketundukan kepada ajaran agama. Dalam hadist diungkapan "Kesucian

${ }^{1}$ www.wikipedia.org. Diambil tanggap 17 Maret 2011.

${ }^{2}$ Bandingkan dalam Ibn Rusyd, Bidâyah al-Mujtahid, diterjemahkan oleh A.Hanafi (Jakarta : Bulan Bintang, 1966) h.107. Juga dalam Taqiyyuddin, Kifâyab al-akbyâr (Indonesia : Dar Ihya' al-Kutub al-'Arabiyah, tt) h. 37 
(fitrah) itu ada lima: khitan, mencukur bulu kemaluan, mencabut bulu ketiak, memendekkan kumis dan memotong kuku" (H.R. Bukhari Muslim). ${ }^{3}$ Oleh karena itulah, biasanya di hari ketujuh sesudah satu hari kelahiran si bayi muslim (laki-laki) dilakukan khitan tetapi hal ini tidak mutlak, ada juga yang melakukan khitan di umur-umur tertentu. ${ }^{4}$ Mayoritas dokter menyarankan bahwa khitan terbaik dilakukan pada pertengahan umur 15 tahun. Hal ini dimaksudkan untuk memberikan waktu kepada jaringan penis yang masih lunak dan berbahaya jika rusak untuk menyatu dan menguat. Mengkhitan pada usia dibawah yang dianjurkan diatas memang boleh dilaksanakan, namun hasil akhir yang didapat bisa sama sekali berbeda, bahkan mendapatkan hasil yang tidak diinginkan walaupun dokter telah berupaya sebaik mungkin. ${ }^{5}$

Hasil pengamatan gambar-gambar di gua yang berasal dari Zaman Batu dan makam Mesir purba mengindikasikan bahwa khitan sebenarnya tidak saja dilakukan oleh umat Islam tetapi telah dilakukan sejak zaman prasejarah. Adapun alasan tindakan ini dilakukan masa itu masih belum jelas tetapi sebagian ahli memperkirakan bahwa tindakan ini merupakan bagian dari ritual pengorbanan atau persembahan, tanda penyerahan pada Yang Maha Kuasa, langkah menuju kedewasaan, tanda kekalahan atau perbudakan, atau upaya untuk mengubah estetika atau seksualitas. ${ }^{6}$

\section{a. Hukum Khitan}

Dalam fikih Islam, hukum khitan dibedakan antara untuk laki-laki dan perempuan. Para ulama berbeda pendapat mengenai hukum khitan baik untuk laki-laki maupun perempuan.

${ }^{3}$ Dalam kitab al-Mu'jam al-mufahras li alfâdri al-badîts yang meriwayatkan hadis tentang ini diantaranya adalah Muslim, Nasa'i, Ibn Majah dalam bab thaharah, kemudian Imam Malik dalam al-Muwatha' dalam bagian shifah an-Nabi serta Ahmad bin hanbal. Lihat A. J. Wensinck, "Ikhtatana", al-Mu'jam al-mufahras li alfâdzi al-hadits, juz II (Leiden : E. J. Brill, 1943) h. 11

${ }^{4}$ Mircea Eliade (ed.), "Circumcision", dalam The Encyclopedia of Religion, buku ke III (tt: Macmillan Publishing Company, 1987) h. 511-514 dalam www.male-initiation.net. Teks aslinya adalah sebagai berikut: Muslim circumcision usually occurs on what is termed the seventh day (in fact it is the eighth day, since the day of birth is not counted). In practice, the time varies widely. Some Muslims perform circumcision within the first five or six years; others delay it until as late as adolescence.

${ }^{5}$ www.wikipedia.org. Diambil tanggal 17 Maret 2011.

${ }^{6}$ Ibid. 


\section{1). Hukum Khitan Laki-Laki}

Menurut jumhur (mayoritas ulama), hukum khitan bagi laki-laki adalah wajib. Para pendukung pendapat ini adalah imam Syafi'i, Ahmad, dan sebagian pengikut imam Malik. Imam Hanafi mengatakan khitan wajib tetapi tidak fardhu. $^{7}$

Menurut riwayat populer dari imam Malik beliau mengatakan khitan hukumnya sunnah. Begitu juga riwayat dari imam Hanafi dan Hasan al-Basri mengatakan sunnah. Namun bagi imam Malik, sunnah kalau ditinggalkan berdosa, karena menurut madzhab Maliki sunnah adalah antara fadhu dan nadb. Ibnu abi Musa dari ulama Hanbali juga mengatakan sunnah muakkadah. ${ }^{8}$

Ibnu Qudamah dalam kitabnya al-Mughni mengatakan bahwa khitan bagi lelaki hukumnya wajib dan kemuliaan bagi perempuan, andaikan seorang lelaki dewasa masuk Islam dan takut khitan maka tidak wajib baginya, sama dengan kewajiban wudhu dan mandi bisa gugur kalau ditakutkan membahayakan jiwa, maka khitan pun demikian. ${ }^{9}$ adalah $:^{10}$

Adapun dalil yang dijadikan landasan ketidak wajiban khitan diantaranya

1. Salman al-Farisi ketika masuk Islam tidak disuruh khitan;

2. Hadis yang berbunyi "Kesucian (fitrah) itu ada lima: khitan, mencukur bulu kemaluan, mencabut bulu ketiak, memendekkan kumis dan memotong kuku" (H.R. Bukhari Muslim). Hadis ini menyebutkan khitan dalan rentetan amalan sunnah seperti mencukur bulu ketiak dan memendekkan kuku, maka secara logis khitan juga sunnah.

Adapun dalil-dalil yang dijadikan landasan normatif para ulama yang mengatakan khitan wajib diantaranya adalah:

1. Dari Abu Hurairah yang mengatakan bahwa nabi Ibrahim melaksanakan khitan ketika berumur 80 tahun, beliau khitan dengan menggunakan kapak. (H.R. Bukhari). ${ }^{11}$ Nabi Ibrahim melaksanakannya ketika

\footnotetext{
7Ahmad Syarbashi, Yas'alûnaka fi al-Dîn wa al-Hayâh, jilid II (Beirut : Dar al-Jil, 1977) h. 31

${ }^{8}$ Ibid.

'Ibnu Qudamah, al-Mughni, juz 12 (Kairo: Hajr, 1992) h. 529

${ }^{10}$ Muhammad Niam, "Ajaran Khitan dalam Islam”, dalam www.pesantervitrual.com. Diambil tanggal 17 Maret 2011.

${ }^{11}$ Dalam kitab al-Mu'jam al-mufahras li alfâdzi al-haditts yang meriwayatkan hadis tentang ini diantaranya adalah Bukhari dalam bab anbiyâ', isti'dzân, Muslim dalam bab fadha'il, serta Ahmad
} 
diperintahkan untuk khitan padahal beliau sudah berumur 80 tahun. Ini menunjukkan betapa kuatnya perintah khitan.

2. Kemudian hadis riwayat Abu Dawud dan Ahmad yang menyatakan bahwa Rasulullah s.a.w. berkata kepada Kulaib: "Buanglah rambut kekafiran dan berkhitanlah". ${ }^{12}$ Perintah Rasulullah s.a.w. menunjukkan kewajiban.

Adapun argumen logis kewajiban khitan ini diantaranya adalah $:^{13}$

1. Kulit yang di depan alat kelamin terkena najis ketika kencing, kalau tidak dikhitan maka sama dengan orang yang menyentuh najis di badannya sehingga sholatnya tidak sah. Sholat adalah ibadah wajib, segala sesuatu yang menjadi prasyarat sholat hukumnya wajib.

2. Diperbolehkannya membuka aurat pada saat khitan, padahal membuka aurat sesuatu yang dilarang. Ini menujukkan bahwa khitab wajib, karena tidak diperbolehkan sesuatu yang dilarang kecuali untuk sesuatu yang sangat kuat hukumnya.

3. Memotong anggota tubuh yang tidak bisa tumbuh kembali dan disertai rasa sakit tidak mungkin kecuali karena perkara wajib, seperti hukum potong tangan bagi pencuri.

\section{2). Hukum Khitan Perempuan}

Hukum khitan bagi perempuan telah menjadi perbincangan para ulama. Sebagian mengatakan itu sunnah dan sebagian mengatakan itu suatu keutamaan saja dan tidak ada yang mengatakan wajib. ${ }^{14}$ Perbedaan pendapat para ulama seputar hukum khitan bagi perempuan tersebut disebabkan riwayat hadis seputar khitan perempuan yang masih dipermasalahkan kekuatannya.

Hadis paling populer tentang khitan perempuan adalah hadis Ummi 'Atiyah r.a., yang berbunyi "Wahai Umi Atiyah, berkhitanlah dan jangan berlebihan, sesungguhnya khitan lebih baik bagi perempuan dan lebih menyenangkan bagi suaminya". Hadist ini diriwayatkan oleh Baihaqi, Hakim dari Dhahhak bin Qais. Abu Dawud juga meriwayatkan hadis serupa namun semua riwayatnya dhaif dan tidak ada yang kuat. Abu Dawud sendiri konon

bin hanbal. Lihat A. J. Wensinck, "Ikhtatana", al-Mu'jam al-mufahras li alfâdzi al-hadîts, juz II (Leiden : E. J. Brill, 1943) h. 11

${ }^{12}$ Dalam kitab al-Mu'jam al-mufahras li alfâdzri al-hadîts yang meriwayatkan hadis tentang ini diantaranya adalah Daud dalam bab thaharah dan Ahmad bin hanbal. Ibid.

${ }^{13}$ Muhammad Niam, "Ajaran Khitan dalam Islam", dalam www.pesantervitrual.com. Diambil tanggal 17 Maret 2011.

${ }^{14}$ Ahmad Syarbashi, Yas'alûnaka fi al-Dîn wa al-Hayâh, h. 31-32 
meriwayatkan hadis ini untuk menunjukkan kedhaifannya. Demikian dijelaskan oleh Ibnu Hajar dalam kitab Talkbîshul Khabîr. ${ }^{15}$

Mengingat tidak ada hadist yang kuat tentang khitan perempuan ini, Ibnu Hajar meriwayatkan bahwa sebagian ulama Syafi'iyah dan riwayat dari imam Ahmad mengatakan bahwa tidak ada anjuran khitan bagi perempuan. ${ }^{16}$

Sebagian ulama mengatakan bahwa perempuan Timur (kawasan semenanjung Arab) dianjurkan khitan, sedangkan perempuan Barat dari kawasan Afrika tidak diwajibkan khitan karena tidak mempunyai kulit yang perlu dipotong yang sering mengganggu atau menyebabkan kekurang nyamanan perempuan itu sendiri. ${ }^{17}$

\section{Tradisi Basunat}

Menurut Noorhaidi Hasan, basunat di daerah Banjar telah ada sejak permulaan abad 20 sebagaimana dilaporkan oleh Schrieke, seorang sarjana Belanda. ${ }^{18}$ Basunat ini harus dilakukan terhadap anak-anak Banjar, sebab jika tidak demikian maka keislamannya belum sempurna. Hal ini dibuktikan jika ada orang yang baru masuk Islam bahkan dalam beberapa kasus perkawinan wanita yang belum disunat diharuskan menjalaninya beberapa hari menjelang perkawinannya. ${ }^{19}$

Berdasarkan laporan Schrieke, basunat laki-laki biasanya dilaksanakan pada umur 10-13 tahun. ${ }^{20}$ Namun penelitian Alfani Daud menunjukkan bahwa anak laki-laki dikhitan pada umur 6-12 tahun meskipun kadang-kadang juga diatas umur tersebut. ${ }^{21}$ Pada hari upacara diadakan, si anak tersebut berendam dalam air beberapa saat. Sementara keluarganya menyiapkan sesajen, piduduk, yang berisi lilin, pisau, beras, kelapa dan gula aren. Menurut Alfani Daud, piduduk ini selain yang disebutkan sebelumnya ada juga yang ditambah dengan

${ }^{15}$ Muhammad Niam, "Ajaran Khitan dalam Islam”, dalam www.pesantervitrual.com. Diambil tanggal 17 Maret 2011.

${ }^{16}$ Ibid.

${ }^{17}$ Ibid.

18 Noorhaidi Hasan, "Ritual "Basunat" : Islam dan Budaya Lokal Dalam Upacara Khitan Muslim Banjar”, Makalah, h. 3

${ }^{19}$ Alfani Daud, Islam dan Masyarakat Banjar (Jakarta : PT. RajaGrafindo Persada, 1997) h. 252

${ }^{20}$ Noorhaidi Hasan, "Ritual "Basunat" : Islam dan Budaya Lokal Dalam Upacara Khitan Muslim Banjar", h. 3

${ }^{21}$ Alfani Daud, Islam dan Masyarakat Banjar, h. 252 
rempah-rempah dapur dan uang secukupnya. ${ }^{22}$ Selain itu, disiapkan pula seperangkat pakaian perempuan dan sebuah sarung serta cincin emas. Sesudah acara basunat ini selesai, maka pada malam harinya diadakan selamatan yang dihadiri sekitar 30-40 orang tetangga dekat. ${ }^{23}$

Catatan Alfani Daud menunjukkan bahwa si anak laki-laki yang disunat harus berendam dalam air bercampur tanah liat atau air dingin saja sejak subuh. Hal ini dimaksudkan untuk mengurangi rasa sakit dan pendarahan waktu operasi. Setelah badan si anak dibersihkan dan dikeringkan lalu ia diberi kalung jeruk nipis, bawang tunggal dan daun jariangau yang dipakai hingga sembuh. Ini dimaksudkan agar si anak tidak pusing kepalanya dan tidak diganggu makhluk halus yang jahat. Operasi sunat dilakukan pada pagi hari atau sebelum tengah hari agar rasa sakit dan pendarahan agak berkurang karena udara pagi yang masih dingin. Potongan kulup penis ditampung dalam bejana kuningan, sasanggan, yang telah diisi dengan abu untuk selanjutnya nanti ditanam di dalam batang pisang atau di bawah pohon melati. Setelah selesai disunat lalu si anak dipakaikan sarung batik (kain sarung perempuan), gelang dan kalung emas dan berbagai hiasan indah lainnya. Bahkan ada juga yang diharuskan bersolek seperti perempuan. Hal ini dilakukan untuk mengecoh makhluk jahat yang ingin mengganggu agar makhluk tersebut mengira bahwa anak laki-laki yang disunat tersebut adalah perempuan. Pada siang harinya baru diadakan acara selamatan dan tiga hari kemudian diadakan acara batumbang (pemberkatan terhadap anak agar kehidupannya selalu sejahtera). ${ }^{24}$

Menurut pengalaman pribadi Noorhaidi Hasan, sebelum basunat si anak laki-laki dicukur dan dimandikan dulu. Kemudian disediakan sarung wanita dan dilehernya dikalungi emas dan permata. Di telapak kaki si anak digambarkan cacak burung, garis silang, dengan kapur yang dicampur daun sirih. Waktu prosesi basunat si anak ditutup matanya oleh salah satu yang ada di sekitarnya. Sementara itu, para wanita mempersiapkan makanan selamatan yang akan diadakan pada malam harinya. Selamatan ini diisi dengan pembacaan maulid Diba’i, biografi dan syair pujian terhadap Nabi saw. Ketika sampai pada ashraqal, bagian yang menceritakan tentang kelahiran Nabi saw, anak yang basunat dibantu oleh keluarganya keluar dari ruangan dan berjalan mengelilingi

22Ibid., h. 256

${ }^{23}$ Noorhaidi Hasan, "Ritual "Basunat" : Islam dan Budaya Lokal Dalam Upacara Khitan Muslim Banjar", h. 3-4

${ }^{24}$ Alfani Daud, Islam dan Masyarakat Banjar, h. 254 
para hadirin di ruang pembacaan itu. Satu persatu para hadirin memoles kepala si anak dengan minyak wangi. Kemudian selamatan ditutup dengan doa. ${ }^{25}$

Apabila operasi basunat ini dilakukan di tempat yang jauh dari tempat kediaman si anak maka biasanya diadakan selamatan dan upacara tapung tawar, ${ }^{26}$ kemudian dibacakan shalawat dan penghamburan beras kuning waktu berangkat. Waktu kembalinya diadakan selamatan kembali atau bisa juga diadakan pada waktu malamnya. Pada sebagian masyarakat ada juga yang mengharuskan diadakannya acara balambur yakni pembacaan syair dengan diiringi permainan tarbang (sejenis rebana besar). ${ }^{27}$

Dalam proses penyembuhan basunat, si anak (laki-laki) biasanya dikenakan berbagai larangan. Diantaranya adalah dilarang tidur miring dan berjalan melangkahi tahi ayam. Secara praktis, larangan tidur miring dianggap bisa mengakibatkan sentuhan-sentuhan yang membawa terbukanya kembali luka hasil operasi. Adapun larangan melangkahi tahi ayam meniscayakan keberhati-hatian dalam berjalan.

Upacara basunat juga terjadi pada perempuan Banjar. Perempuan Banjar disunat pada umur yang lebih muda dari laki-laki. ${ }^{28}$ Ada yang berpendapat sebelum berumur tiga bulan, ${ }^{29}$ ada juga yang mengatakan ketika berusia satu tahun. ${ }^{30}$ Berbagai selamatan dan usaha pencegahan dilakukan. Tindakan batumbang (pemberkatan) dilakukan sesudah disunat. Kepada si anak perempuan ini dikalungkan juga jeruk nipis, bawang tunggal dan daun jariangau serta berbagai perhiasan emas yang berguna sebagai pikaras (memperkuat semangat) baginya. Namun bagi perempuan tidak ada pantangan sesudah basunat. ${ }^{31}$

Saat ini, tradisi basunat meski masih ada yang melaksanakan namun semakin memudar. Mulai mengikisnya tradisi ini tentu saja ada hubungan

${ }^{25}$ Noorhaidi Hasan, "Ritual "Basunat" : Islam dan Budaya Lokal Dalam Upacara Khitan Muslim Banjar", h. 5

${ }^{26}$ Tapung tawar yakni sebuah ritual keselamatan.

${ }^{27}$ Alfani Daud, Islam dan Masyarakat Banjar, h. 255

${ }^{28}$ Ibid., h. 252

${ }^{29}$ Noorhaidi Hasan, "Ritual "Basunat" : Islam dan Budaya Lokal Dalam Upacara Khitan Muslim Banjar", h. 4

${ }^{30} \mathrm{M}$. Suriansyah Ideham, et.al (ed.), Urang Banjar dan Kebudayaannya (Banjarmasin: Badan Penelitian dan Pengembangan Daerah Kal-Sel, 2005) h. 57

${ }^{31}$ Alfani Daud, Islam dan Masyarakat Banjar, h. 256 
dengan perkembangan modern yang mengedepankan rasionalitas. ${ }^{32}$ Dalam konteks modern, tindakan-tindakan rasional menggantikan peran agama yang sangat berpengaruh pada kehidupan komunal. Ungkapan seperti supaya kada ngalih ini itu; nang wajibnya baja (supaya tidak mempersulit diri), ketika ditanya kenapa tidak dilaksanakan upacara basunat pada bagian masyarakat, dan makin maraknya khitan massal, adalah gambaran menipisnya tradisi basunat dan kuatnya pengaruh rasionalitas modern. ${ }^{33}$ Secara rasional dan pragmatis, memang basunat dengan berbagai ritualnya tidak praktis, dan khitan massal bisa jadi bernilai gratis.

\section{Makna Antropologis}

Basunat merupakan masa peralihan. Masa peralihan adalah masa yang genting dan penting bagi seorang individu. Menurut Victor Turner, dimasa peralihan, transisi, inilah seseorang dihadapkan pada kondisi liminal yakni kondisi ambang pintu, tidak di sini dan tidak di sana, kondisi tengah-tengah. Ibarat dua buah ruangan (ruangan A dan B) yang ditengahi oleh sebuah pintu, maka kondisi liminal adalah pintu antara ruang A dan B tersebut. Pada kondisi inilah, individu yang mengalami peralihan mengalami keadaan bebas struktur. Bebas struktur berarti tidak adanya simbol-simbol struktur yang sering digunakan dalam aktivitas sehari-hari. Dalam kondisi ini seseorang tidak diidentifikasi sebagai si kaya atau si miskin atau identitas hirarkis lainnya. Dalam kondisi ini terjadi spontanitas, kelangsungan, kebebasan dan kesamaan. Dalam kondisi ini pula, saat-saat "jeda" untuk melakukan tindakan reflektif formatif sebagai persiapan untuk memaknai dan menjalani hidup selanjutnya.

Jika diskemakan maka tahapan liminalitas basunat tersebut diawali oleh tahap separasi (pemisahan), kemudian tahap liminal, lalu tahap reaggregation

\footnotetext{
${ }^{32}$ Secara filosofis, filsafat positivisme yang didirikan Auguste Comte mengantarkan kemajuan modern saat ini. Dalam paham filsafat ini, tahap sejarah manusia itu dibagi menjadi tiga yakni tahap teologis, metafisik dan positif. Tahap teologis adalah tahap keyakinan bahwa segala yang ada adalah perbuatan ilahi, kemudian tahap metafisik adalah tahap depersonalisasi tahap teologis tersebut, dan tahap positif adalah tahap kedewasaan dan kemajuan karena manusia tidak bergantung lagi kepada sesuatu di luar dirinya seperti Tuhan. Bandingkan dalam Anonim, "Positivism and Logical Empiricism", dalam The New Encyclopaedia Britannica, Vol. 14 (Chicago : Encyclopaedia Britannica, Inc., 1979) h. 877. Donny Gahral Adian, Arus Pemikiran Kontemporer (Yogyakarta : Jalasutra, 2001). Juga dalam M. Rusydi, Teori Kritis Juergen Habermas dan Relevansinya dengan Fundamentalisme Islam (Banjarmasin: Antasari Press, 2003) h. 54-56.

${ }^{33}$ Noorhaidi Hasan, "Ritual "Basunat" : Islam dan Budaya Lokal Dalam Upacara Khitan Muslim Banjar”, h. 15-16
} 
(penyatuan) yakni kembali ke masyarakat. Adapun ilustrasi kondisi-kondisi tersebut adalah sebagai berikut: ${ }^{34}$

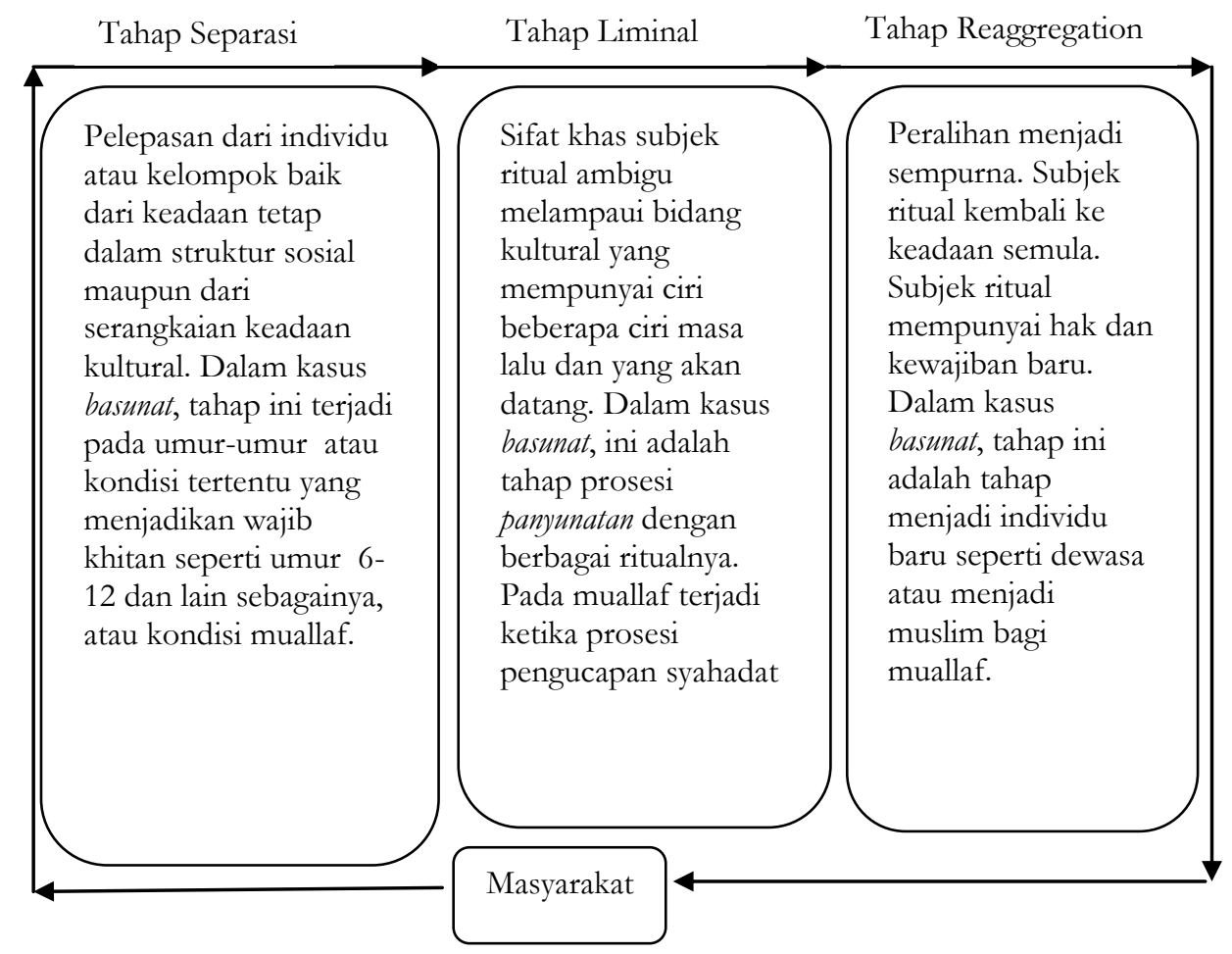

Selanjutnya, tradisi basunat sebagai sebuah kondisi penting dan genting, sebagaimana diuraikan sebelumnya, tak jarang diawali dengan berendam di air atau bercukur. Hal ini mengindikasikan tindakan penyucian diri. Penyucian diri agar hubungan dengan kekuatan adi kodrati dapat tercapai. Hubungan dengan adi kodrati mampu memberi kekuatan untuk menghadapi situasi genting ini. ${ }^{3}$

Namun, penyucian diri tidaklah cukup untuk melewati masa kritis tersebut. Perlu pula disertakan persembahan berupa piduduk dan perlindungan cacak burung. Kedua hal ini mampu membantu subjek ritual mempertahankan

${ }^{34}$ Bandingkan dengan Wartaya Winangun, Masyarakat Bebas Struktur (Yogyakarta : Kanisius, 1990) h. 36.

${ }^{35}$ Noorhaidi Hasan, "Ritual "Basunat" : Islam dan Budaya Lokal Dalam Upacara Khitan Muslim Banjar", h. 9 
diri dari gangguan roh-roh jahat. Piduduk juga membimbing subjek ritual untuk memasuki status sosial yang baru. Lilin menjadi simbol penerang kehidupan, pisau memiliki makna sebagai senjata menghadapi rintangan hidup serta kejantanan dan keberanian, kemudian beras, kelapa, gula aren, rempah-rempah dapur merupakan simbol kesuburan dan kesejahteraan yang akan dinikmati oleh seluruh individu yang terlibat dalam tradisi tersebut. ${ }^{36}$

Basunat sendiri bisa juga dianggap sebagai wadah untuk mengekspresikan sikap cemburu terhadap kemampuan prokreatif kaum perempuan. Dengan kata lain, kaum laki-laki tidak mau kalah dengan kemampuan perempuan yang bisa hamil dan melahirkan anak yang berarti bahwa perempuan mampu memberikan kehidupan. Dalam konteks inilah, basunat menggambarkan bahwa laki-laki juga mampu berikan kehidupan bahkan kehidupan yang lebih abadi dibandingkan dengan kehidupan yang diberikan perempuan, karena kehidupan yang diberikan laki-laki dihubungkan dengan kekuatan adi kodrati dan kepasrahan kepada-Nya. Simbolisasi keabadian hidup tersebut diekspresikan ketika tukang sunat menggunakan pisau atau gunting untuk memotong kulit kelamin laki-laki, ia berakting layaknya seorang penyembelih dalam upacara korban besar. Mata anak yang disunat ditutup sebagai wujud kepasrahan untuk dikorbankan atas nama Tuhan supaya dapat menerima keabadian hidup kelak. Dalam hal ini, basunat dimaksudkan untuk membawa kelahiran kembali (reincarnation) dan menjamin keinginan realisasi kehidupan sesudah mati. Jadi layaknya upacara korban besar, dimana suatu realitas dibangun dan ditampakkan kemampuan laki-laki memberi keabadian dan kelahiran kembali, begitu juga yang terjadi pada tradisi basunat. Dan disinilah campur tangan lakilaki dalam wilayah prokreatif perempuan. ${ }^{37}$

Selain itu basunat sendiri adalah peristiwa berdarah dan menyakitkan. Peristiwa ini sangat penting untuk laki-laki agar ia lepas dari keterikatan dan kedekatannya dengan ibunya. Dengan kata lain, ketika kecil si anak laki-laki tersebut selalu bersama dan dekat dengan ibunya. Kemudian terjadi basunat (peristiwa berdarah dan menyakitkan) maka berarti ia telah dikenalkan dengan dunia luar (ruang publik) yakni dunia para laki-laki yang penuh tantangan dan kesulitan yang mungkin akan dihadapinya dengan penuh darah dan penderitaan. Hal ini berbeda dengan basunat perempuan yang ketika terjadi

\footnotetext{
${ }^{36}$ Ibid., h. 9-10

${ }^{37}$ Ibid., h. 11
} 
pemotongan kelentit berarti merenggutnya dari dunia luarnya, karena ia telah menjadi seorang wanita yang layak diberi tanggung jawab kewanitaan. ${ }^{38}$

Selanjutnya, upacara selamatan dalam basunat menggambarkan kesatuan kelompok sosial dari individu yang disunat. Kelompok sosial ini merujuk kepada ikatan keluarga dan lingkungan sekitar dan tidak melibatkan "orang luar". Ketika selamatan ini terjadi, batas-batas struktural kelompok menjadi kabur dan tipis sehingga bisa berfungsi untuk meminimalisir ketegangan dan konflik dalam kelompok tersebut. ${ }^{39}$

\section{Makna Filosofis}

Makna antropologis dalam pemahaman liminalitas di atas menggambarkan suatu kondisi reflektif formatif yang bisa digunakan manusia sebagai kesempatan untuk memperbaharui pemahaman eksistensialnya (keberadaannya). Aktivitas memahami eksistensi ini akan menjadikan manusia yang melakukannya menjadi individu baru dan lebih sempurna. Lalu bagaimana sebenarnya hubungan eksistensial manusia tersebut dengan tradisi basunat yang dilakukan masyarakat Banjar tersebut?

Secara filosofis, problem esensi dan eksistensi merupakan salah satu tema ontologis yang sering dibahas. Problem esensi dan eksistensi adalah problem rumit yang telah mendapat tanggapan yang beragam dari berbagai filosof. ${ }^{40}$ Dalam tradisi Islam esensi disebut dengan mâbiyyah (ke-apa-an) sedangkan eksistensi disebut dengan wujûdiyyah (keber-ada-an). ${ }^{41}$ Sebenarnya,

${ }^{38}$ Ibid., h. 11-12

${ }^{39}$ Ibid., h. 12-13

${ }^{40}$ Dalam tradisi Barat, masalah eksistensial mulai dibahas pada awal abad ke-19 oleh Kierkegaard (1813-1855) dan Nietzsche (1844-1900), kemudian istilah analisis eksistensial pertama kali digunakan oleh Martin Heidegger (1889-1976) dalam Time and being. Selanjutnya diikuti oleh J.P. Sastre (1905-1980), Karl Jasper (1885-1969), G. Marcel (1889-1973), Ortega Y. Gasset (1883-1955), Paul Tillich (1886-1965) dan lain sebagainya. Lihat Zainal Abidin, Analisis Eksistensial (Jakarta : Rajawali Press, 2007) h. 5-6.

${ }^{41}$ Contoh untuk mabiyah dan wijûdiyyah ini adalah : ketika kita melihat seorang manusia, maka ada dua hal yang bisa dipisahkan dari manusia tersebut yakni "apanya"(esensi) dan "adanya" (eksistensi). Jika ditanya apa ini ? maka jawabannya adalah ini manusia. Dan jika ditanya adanya? Maka yang dijelaskan adalah makna keberadaan manusia yang beragam dari berbagai individu, misalnya, dalam hubungannya dengan Tuhan, sesama manusia dan dirinya sendiri, serta alam sekitarnya. Dan lain sebagainya yang berhubungan dengan keberadaannya. Jika pada esensi yang beroperasi adalah wilayah konseptual maka pada eksistensi adalah wilayah konkrit dan bersifat aktual. Bandingkan!!, uang 100 juta dalam pikiran (ini bersifat esensi), dan uang 100 juta yang nyata ada di tangan (ini bersifat eksistensi). 
pada wilayah eksternal, antara esensi dan eksistensi adalah sebuah kesatuan yang tak bisa dipisahkan layaknya sebuah mata uang yang memiliki dua sisi (dua gambar). Namun untuk kepentingan konseptual dua hal tersebut dibedakan untuk memahami yang mana lebih dulu dan yang sebenarnya nyata. Berbagai jawaban diberikan untuk pertanyaan tersebut, ada yang mendukung esensi dan ada juga yang mendukung eksistensi. Dalam konteks filsafat Islam, eksistensilah sementara ini jawaban yang dianggap mumpuni sebagai hasil visi intelektual tokoh terkemuka Persia, Mulla Shadra. ${ }^{42}$ Berdasarkan tradisi Islam inilah tulisan ini "membaca" tradisi basunat Banjar karena eksistensi dalam makna filsafat Barat menekankan temporalitas dibandingkan tradisi Islam yang

${ }^{42}$ Perdebatan esensi dan eksistensi diawali dengan pemahaman teologis Mu'tazilah yang beranggapan bahwa esensi dan eksistensi adalah sama-sama riil namun eksistensilah yang lebih dulu daripada esensi. Struktur realitas yang ditawarkan adalah polaritas mutlak dan nisbi. Hasil pemahaman ini didapatkan dari metode keilmuan rasio dan wahyu. Selanjutnya problem ini ditanggapi oleh Ibn Sina (Hikmah Masya'iyah) yang menggunakan metode dan anggapan sama yang sama dengan Mu'tazilah bahwa esensi dan eksistensi adalah riil dan eksistensi lebih dulu dari esensi namun struktur realitas yang ditawarkan adalah jenjang eksistensi yakni ada yang primer dan sekunder. Kemudian ditanggapi kembali oleh Suhrawardi (Hikmah Isyraqiyyah) bahwa eksistensi hanya bersifat mental sedangkan esensi adalah yang sebenarnya nyata. Sehingga esensilah yang lebih dulu daripada eksistensi. Struktur realitas yang ditawarkan adalah gradasi (tasykik) esensi yakni esensi itu ada yang lebih sempurna atau kurang sempurna. Pemahaman ini dihasilkan dari metode rasio, intuisi dan wahyu. Pada tahap selanjutnya, problem ini ditanggapi oleh tokoh tasawuf falsafi Ibn Arabi (irfan wujudiyyah) yang beranggapan bahwa yang sebenarnya riil adalh eksistensi dan esensi adalah bersifat mental sehingga eksistensi lebih dulu daripada esensi. Ia menawarkan struktur realitas berupa jenjang esensi yakni realitas fisik hanyalah pantulan dari dunia a'yan tsabitab (realitas yang tetap), semacam dunia idea dalam pemahaman Plato. Pemahaman ini dihasilkan dari refleksi intuisi dan wahyu. Dan tokoh fenomenal yang dianggap mampu meramu semua proses diatas adalah Mulla Shadra atau Shadra al-Din al-Syirazi (Hikmah Muta'aliyah). Menurutnya yang sebenarnya nyata adalah eksistensi dan esensi adalah subordinasi. Eksistensi mendahului esensi. Dan struktur realitas adalah bersifat gradasi eksistensi (tasykîk al-wujûd) yakni eksistensi itu ada yang lebih sempurna atau kurang sempurna, tergantung kedekatannya dengan eksistensi murni, namun semua eksistensi bergerak dinamis karena adanya gerakan substansi (barakah al-jawhariyah). Pemahaman ini dihasilkan dari metode rasio, intuisi dan wahyu. Fazlurrahman, Filsafat Shadra (Bandung : Pustaka, 2000) h. xvi 
menekankan transendensi dan etenalitas ${ }^{43}$, selain itu masyarakat Banjar dikenal sebagai masyarakat yang identik dengan keislamannya. ${ }^{44}$

Dalam Islam, menurut Musa Asy'arie, esensi dianggap berakhir pada Allah dan untuk mendapatkan hakikat dan kualitas esensi ini maka diperlukan sejumlah proses eksistensial. Proses ini meniscayakan pergulatan, konflik dan ketegangan mencari bentuk, dalam mewujudkan diri secara optimal. Eksistensi tidak pernah berada dalam ruang kosong bahkan selalu berhadapan dan bertabrakan dengan eksistensi-eksistensi lainnya. ${ }^{45}$

Basunat sebagai kondisi liminal menggambarkan pergulatan dan konflik serta ketegangan pencarian bentuk yang lebih optimal tersebut. Basunat merupakan proses perjalanan eksistensi seorang manusia dari anak-anak menuju tahap lanjutan yakni kedewasaan. Makna anak-anak secara psikologis dipahami sebagai kondisi yang cenderung kepada fantasi dan fokus pada diri sendiri sedangkan makna dewasa adalah sebaliknya yakni cenderung pada realitas dan bisa memperhatikan orang lain. ${ }^{46}$ Bahkan dalam konteks fikih, seorang yang belum basunat akan dikategorikan sebagai "najis" dan tidak layak melaksanakan beberapa aktivitas yang meniscayakan kesucian diri, seperti shalat, nikah. Jadi hal ini menggambarkan upaya menjadi individu yang optimal. Mulla shadra bahkan berpendapat, segala sesuatu mengalami gerak substansi (evolusi spiritual) dan secara terus menerus menuju bentuk yang lebih sempurna dalam upaya aktualisasi wujudnya karena adanya tarikan dari yang Maha Wujud. ${ }^{47}$ Dengan kata lain, eksistensi individu muslim banjar akan

${ }^{43}$ Filsafat eksistensial Barat hanya mempercayai nilai-nilai kehidupan temporal, sebab manusia adalah sendirian dan ia harus menerima fakta bahwa masa depannya terancam oleh ketiadaan dan kepunahan total. Tidak ada eksistensi absolut, Maha Kuasa, yang dirindukan. Oleh karena itu, tujuan filsafat ini adalah kemanusiaan yang bersifat temporer seperti perlawanan kepada ketidakadilan sosial. Dalam bahasa arab bentuk filsafat ini bisa disebut dengan nama ashâlah al-hâyah, karena hidup di dunia ini saja yang jadi dasar utamanya. Sementara filsafat eksistensial Islam menekankan bahwa manusia itu tidak terpisah dengan Tuhan, eksistensi absolut. Manusia selalu bersentuhan dengan Tuhan dan keabadian. Jika manusia menyadari kewajiban ontologisnya, dengan menyingkirkan ketergantungan duniawi maka ia akan menikmati hidup abadi. Singkatnya manusia memiliki masa depan sesudah kehidupan dunia ini. Syaifan Nur, Mulla Shadra (Jakarta: Teraju Mizan, 2003) h. 96-97. Bandingkan juga dalam Lorens Bagus, "Eksistensi”, Kamus Filsafat (Jakarta : Gramedia, 1996) h. 183

${ }^{44}$ Alfani Daud, Islam dan Masyarakat Banjar, h. 5

${ }^{45}$ Musa Asy'arie, Filsafat Islam (Yogyakarta : LESFI, 2010) h. 52-53

${ }^{46}$ Abubakar Baradja, Psikologi Perkembangan (Jakarta : Studia Press, 2005) h. 6

${ }^{47}$ Bandingkan dalam Fazlurrahman, Filsafat Shadra (Bandung: Pustaka, 2000). 
teralienasi jika tidak basunat. Teralienasi berarti kehilangan jati diri dan kehilangan jati diri berarti tidak diakuinya keberadaan oleh yang lain (the others). Dengan kata lain wujûdubu ka 'adamibi (adanya seperti tiadanya). ${ }^{48}$

Basunat dengan berbagai ritusnya juga merefleksikan hubungan manusia dengan Tuhannya, sesamanya, alam dan kebudayaan (ciptaan manusia). Dalam hubungannya dengan Tuhan, ritual basunat diisi dengan aktivitas cukur dan mandi sebagai simbolisasi kesuciannya dari berbagai noda dan dosa, pembacaan maulid Diba'i, biografi dan syair pujian terhadap Nabi. Transendensi tingkah laku ini menggambarkan kehambaan manusia. Kehambaan berarti kelemahan dan ketiadaan otoritas manusia terhadap kuasa Tuhan. Upaya "melawan" Tuhan hanya menghasilkan tindakan sia-sia. Ketidakberdayaan ini digambarkan dengan ketidakmampuan manusia menolak kelahirannya, tidak mampu memilih tempat dan tanggal kelahirannya, bahkan waktu dan tempat kematiannya pun tidak bisa direncanakan manusia dengan tepat tanpa kehendak dari Tuhan. Kalau pun manusia bisa menolak Tuhan layaknya Nietzsche, ${ }^{49}$ Fuerbach, Sigmund Freud, Karl Marx, maka itu hanyalah Tuhan dalam konsepsinya bukan Tuhan dalam arti yang sebenarnya, sebab Tuhan dalam arti sebenarnya tidak bisa dikonsepsi dengan rasio kecuali dengan sesuatu yang suci dan dialami secara langsung yakni dengan intuisi. ${ }^{50}$ Oleh karena itu, ketundukan manusia terhadap Tuhan adalah sesuatu yang sudah dikodratkan, suka atau tidak suka, senang atau terpaksa.

Dalam konteks hubungan manusia dengan sesamanya, ritual basunat menampilkan keharusan seorang anak memakai sarung perempuan dan cincin emas, bahkan ada yang berpakaian dan bersolek layaknya perempuan yang jika didalam kondisi normal akan diejek dan ditertawakan. ${ }^{51}$ Kemudian basunat juga sering diikuti dengan upacara selamatan dengan berbagai hidangan. Dalam hal ini, manusia diingatkan akan eksistensinya bahwa posisinya antara sesama manusia adalah sama dan sederajat baik laki-laki maupun perempuan. Oleh karena itu, hubungan antar individual memiliki kekuasaan yang sama yang

${ }^{48}$ Tentang alienasi ini, Alfani Daud misalnya, menuliskan tentang ungkapan orang-orang tua di Anduhum berkenaan gadis yang tidak atau belum basunat: asa bakalalangan haja kaalah kita,"terasa mengganggu perasaan kita". h. 252.

49"Pembunuhan" Nietzsche terhadap Tuhan bisa dibaca dalam Sunardi, Nietzsche (Yogyakarta : LKIS,1999). Teori-teori Karl Marx bisa juga dibaca dalam Andi Muawiyah Ramly, Peta Pemikiran Karl Marx (Yogyakarta : LKIS, 2000)

${ }^{50}$ Bandingkan Syaifan Nur, Mulla Shadra, h. 89. Lihat juga Musa Asy'arie, Filsafat Islam, h. 126.

${ }^{51}$ Alfani Daud, Islam dan Masyarakat Banjar, h. 254 
meniscayakan setiap individu untuk saling menghormati dan tidak merampas hak yang lainnya, tidak merendahkan satu sama lain. Dengan kata lain, manusia antara sesamanya hendaknya bersikap adil dan menghindari kedzaliman. ${ }^{52}$ Selanjutnya, upacara selamatan menggambarkan sikap untuk senang berbagi. sikap untuk senang berbagi, memberikan bantuan kepada orang lain adalah sebuah keniscayaan bagi manusia sebab hanya dengan saling membantu manusia dapat hidup dalam arti yang sebenarnya. Keberadaan manusia sejak lahirnya menggambarkan ketidakberdayaan. Dari bayi, manusia memerlukan orang-orang yang menyayangi dan melindunginya, ketika menjadi anak-anak, manusia perlu orang-orang yang mendidik dan mengarahkannya, ketika dewasa dan masa tua, manusia perlu orang-orang yang mendampinginya, bahkan ketika meninggal dunia, manusia perlu orang-orang yang membantunya untuk menguburkannya. Oleh karena itu, individu yang mengabaikan sosialnya berarti telah "membunuh" kemanusiaannya sendiri.

Kemudian, hubungan tradisi basunat dengan alam direfleksikan dengan pemakaian kalung jeruk nipis, bawang tunggal dan daun jariangau, piduduk dan proses penyembuhan basunat. Piduduk yang berisi lilin, pisau, kelapa, beras dan gula aren, kemudian jeruk nipis, bawang serta daun jariangau adalah hasil yang diberikan alam kepada manusia. Sementara proses penyembuhan basunat terutama pada anak laki-laki sering dikenakan berbagai larangan seperti dilarang tidur miring dan berjalan melangkahi tahi ayam. Secara praktis, sebagaimana diuraikan sebelumnya, larangan tidur miring dianggap bisa mengakibatkan sentuhan-sentuhan yang membawa terbukanya kembali luka hasil operasi. Adapun larangan melangkahi tahi ayam meniscayakan keberhati-hatian dalam berjalan. Semua tingkah laku ini meniscayakan harmanonisasi manusia dengan alam sebab alam memiliki hukumnya sendiri. Kemampuan memahami dan "berdialog" dengan alam akan memberikan keselamatan dan kesejahteraan bagi manusia itu sendiri namun menghancurkan alam sama dengan menghancurkan diri sendiri sebab manusia itu sendiri memiliki unsur-unsur alam. Sejarah manusia telah menunjukkan bahwa ketika manusia melakukan penebangan liar atau tambang liar dan tak bertanggung jawab, akhirnya merugikan manusia itu sendiri. Keuntungan yang diperoleh hanya sedikit namun penderitaan terjadi di

\footnotetext{
${ }^{52}$ Secara teologis, Asghar Ali berpendapat bahwa Islam adalah agama yang bersifat revolusioner dan selalu memihak kepada keadilan dan mencela kedzaliman. Jika demikian, maka Islam berarti selaras dengan nilai-nilai eksistensial sebagaimana diuraikan diatas. Untuk lebih jelas tentang pendapat Asghar Ali ini baca dalam Asghar Ali Engineer, Islam dan Teologi Pembebasan (Yogyakarta : Pustaka Pelajar,1999)
} 
mana-mana akibat rusaknya alam baik oleh banjir, tanah longsor, gundulnya hutan, dan lain sebagainya. Oleh karena itu, rusaknya alam sama dengan "matinya" manusia sebab ia menjadi kesulitan mencari makanan, kesulitan untuk mengembangkan kebudayaannya dan lain sebagainya. Dalam tradisi basunat manusia diingatkan untuk menjaga harmonisasi dengan alam ini, agar kehidupannya tetap terus lestari dan sejahrera.

Selanjutnya, hubungan manusia dengan budayanya dalam konteks basunat adalah tradisi basunat itu sendiri. Tradisi ini adalah ciptaan manusia, dan sebagai ciptaannya, manusia hendaknya tidak memutlakkannya dan menjadikannya tujuan, tetapi memposisikannya sebagai alat, sebagai refleksi diri atau penguatan sosial, misalnya. Dengan demikian, maka kebudayaan tersebut mampu membantu manusia untuk mencapai kemudahan dan kenyamanan hidup. Namun jika sebaliknya yakni kebudayaan atau ciptaan tersebut dimutlakkan atau dipertuhankan, misalnya tradisi basunat dijadikan sebuah acara yang menunjukkan kelas tertentu dan gengsi sosial dengan menampilkan kecenderungan hawa nafsu maka hal ini tidak membawa kepada perbaikan derajat yang lebih baik. Dan hal ini menjadikan manusia gagal sebagai "aku yang mencipta" sebagai cerminan wakil Tuhan di muka bumi. ${ }^{53}$ Tuhan adalah pencipta yang kreatif sekaligus memberikan keselamatan, kenyamanan, kemudahan dan keamanan, maka hendaknya manusia mencipta dalam makna sebagaimana yang dilakukan Tuhan tersebut. Manusia tanpa ciptaannya adalah manusia tanpa dinamika dan proses. Ketiadaan dinamika dan proses ini sama saja dengan ketiadaan aktualisasi diri dan ini menafikan manusia di dunianya. Jika demikian, maka sama saja manusia mati tanpa kuburan.

Lebih lanjut, basunat juga merefleksikan pluralitas (keberagaman). Pluralitas pada hakikatnya adalah realitas kehidupan itu sendiri, tidak bisa ditolak dan dihindari. Penolakan terhadap pluralitas sama artinya menolak kehidupan itu sendiri karena pluralitas adalah kodrat dan kehidupan yang tidak

${ }^{53}$ Perhatikan kritik kelompok Teori Kritis misalnya terhadap Positivisme yang telah memberikan kemajuan teknologis namun mengakibatkan kemunduran pada dimensi lain seperti dimensi spiritualitas dan ekologis. Manusia cenderung menjadi materialis sehingga spiritualitasnya kering, tidak peduli dengan sesamanya bahkan alam menjadi hancur karenanya. Positivisme telah menjadikan manusia menemukan pesawat terbang namun demi ambisi keberhasilan pesawat terbang tersebut hutan-hutan ditebang secara semena-mena sehingga mengakibatkan ketidak seimbangan ekosistem. Untuk lebih detil tentang kritik ini baca Jurgen Habermas, Knowledge and Human Interests, diterjemahkan Jeremy J. Shapiro (Boston : Beacon Press, 1971). Sindhunata, Dilema Usaba Manusia Rasional : Kritik Masyarakat Modern oleh Marx Horkheimer dalam Rangka Sekolah Frankfrut (Jakarta : Gramedia, 1982). 
mungkin ditiadakan. Oleh sebab itulah tidak pernah ditemukan dalam kehidupan ini dua hal yang sama persis dari berbagai sisi dan aspeknya. Contoh konkrit adalah sidik jari manusia yang selalu berbeda satu sama lain makanya di IAIN Antasari kehadiran sidik jari bisa dilakukan sebab tidak ada yang bisa memalsukan sidik jari ini. Adapun ketegangan pluralitas adalah sesuatu yang alami dan wajar namun harus disikapi dengan bijak sehingga mampu menghasilkan bentuk sintetis yang baru, konstruktif serta menghasilkan kemajuan layaknya mekanisme alam yang menghadirkan bentuk kehidupan yang baru dari konflik yang terjadi. ${ }^{54}$ Basunat adalah bagian dari pluralitas itu sendiri dan ini adalah hasil "dialog" (ketegangan) antara budaya Islam dan budaya lokal, namun tradisi ini mampu menjadikan para individu yang terlibat didalamnya menjadi bagian keberlangsungan keteraturan sosial, sehingga integrasi sosial, kolektifitas dan hirarki di masyarakat tetap terjaga dan terpelihara, dan hal ini bisa memberikan kontribusi pada kesatuan dan kohesi masyarakat Banjar itu sendiri. ${ }^{55}$

Meskipun tradisi basunat di era sekarang sepertinya memudar dan maknanya sebagai kondisi liminal (ambang pintu) secara antropologis juga terkikis namun makna-makna filosofis akan tetap bertahan karena hal ini bersifat fundamental.

\section{Penutup}

Basunat adalah suatu tradisi peralihan yang dilakukan oleh masyarakat Banjar ketika melaksanakan khitan yang diisi dengan berbagai aktivitas ritual. Sementara khitan adalah operasi kecil terhadap alat kelamin dan merupakan praktek keagamaan dalam kalangan umat Islam.

Basunat dengan berbagai ritualnya memiliki berbagai makna. Secara antropologis, basunat bisa dipahami sebagai kondisi liminal, ambang pintu, yang berfungsi sebagai kondisi reflektif formatif dan persiapan untuk menjadi individu baru (dewasa). Sementara secara filosofis, basunat mengingatkan kondisi eksistensial manusia di dunia untuk menjaga keharmonisannya dengan eksistensi-eksistensi lainnya.

Akhirnya, basunat yang mengeskpresikan masyarakat komunal, saat ini mulai memudar dengan perkembangan modern yang mengedepankan rasionalitas. Meskipun demikian, secara filosofis, makna eksistensi manusia dan

\footnotetext{
${ }^{54}$ Musa Asy'arie, Filsafat Islam, h. 58

${ }^{55}$ Noorhaidi Hasan, "Ritual "Basunat" : Islam dan Budaya Lokal Dalam Upacara Khitan Muslim Banjar", h. 2.
} 
hubungannya dengan eksistensi lain harus tetap terjaga dan terpelihara demi kemaslahatan manusia itu sendiri. Wallâhu a'lamu bisshawâb

\section{Daftar Pustaka}

Abidin, Zainal, Analisis Eksistensial, Jakarta, Rajawali Press, 2007.

Adian, Donny Gahral, Arus Pemikiran Kontemporer, Yogyakarta, Jalasutra, 2001

Ali Engineer, Asghar, Islam dan Teologi Pembebasan, Yogyakarta, Pustaka Pelajar,1999

Anonim, The New Encyclopaedia Britannica, Vol. 14, Chicago, Encyclopaedia Britannica, Inc., 1979

Asy’arie, Musa, Filsafat Islam, Yogyakarta, LESFI, 2010

Bagus, Lorens, Kamus Filsafat, Jakarta,Gramedia, 1996

Baradja, Abubakar, Psikologi Perkembangan, Jakarta, Studia Press, 2005

Daud, Alfani, Islam dan Masyarakat Banjar, Jakarta, PT. RajaGrafindo Persada, 1997

Eliade (ed.), Mircea, The Encyclopedia of Religion, buku ke III, tt: Macmillan Publishing Company, 1987

Fazlurrahman, Filsafat Shadra, Bandung, Pustaka, 2000

Habermas, Jurgen, Knowledge and Human Interests, diterjemahkan Jeremy J. Shapiro, Boston, Beacon Press, 1971

Hasan, Noorhaidi, "Ritual "Basunat" : Islam dan Budaya Lokal Dalam Upacara Khitan Muslim Banjar", Makalah.

Muawiyah Ramly, Andi, Peta Pemikiran Karl Marx, Yogyakarta, LKIS, 2000

Nur, Syaifan, Mulla Shadra, Jakarta,Teraju Mizan, 2003

Qudamah, Ibnu, al-Mughni, Kairo, Hajr, 1992

Rusyd, Ibn, Bidâyah al-Mujtahid, diterjemahkan oleh A.Hanafi, Jakarta, Bulan Bintang, 1966

Rusydi, M., Teori Kritis Juergen Habermas dan Relevansinya dengan Fundamentalisme Islam, Banjarmasin, Antasari Press, 2003 
Sindhunata, Dilema Usaba Manusia Rasional : Kritik Masyarakat Modern oleh Marx Horkheimer dalam Rangka Sekolah Frankfrut, Jakarta, Gramedia, 1982

Sunardi, Nietzsche, Yogyakarta, LKIS,1999

Suriansyah Ideham, et.al (ed.), M., Urang Banjar dan Kebudayaannya, Banjarmasin, Badan Penelitian dan Pengembangan Daerah Kal-Sel, 2005

Syarbashi, Ahmad, Yas'alûnaka fi al-Dîn wa al-Hayâh, jilid II, Beirut : Dar al-Jil, 1977

Taqiyyuddin, Kifâyah al-akbyâr, Indonesia, Dar Ihya' al-Kutub al-'Arabiyah, tt.

Wensinck, A. J. , al-Mu'jam al-mufahras li alfâdz̧i al-badîts, juz II, Leiden : E. J. Brill, 1943

Winangun, Wartaya, Masyarakat Bebas Struktur, Yogyakarta, Kanisius, 1990.

www.pesantervitrual.com.

www.wikipedia.org 